\title{
Inhibitory effect of a Brazilian marine brown alga Spatoglossum schröederi on biological activities of Lachesis muta snake venom
}

\author{
Thaisa Francielle Souza Domingos, ${ }^{1,2}$ Fredy A. Ortiz-Ramírez, ${ }^{1}$ \\ Roberto C. Villaça, ${ }^{1}$ Diana N. Cavalcanti, ${ }^{1}$ Eladio F. Sanchez, ${ }^{3}$ \\ Valéria L. Teixeira, ${ }^{1}$ André Lopes Fuly ${ }^{* 2}$
}

\author{
'Programa de Pós-graduação em Biologia Marinha, Instituto de Biologia, \\ Universidade Federal Fluminense, Brazil, \\ ${ }^{2}$ Departamento de Biologia Celular e Molecular, Instituto de Biologia, \\ Universidade Federal Fluminense, Brazil, \\ ${ }^{3}$ Fundação Ezequiel Dias, Centro de Pesquisa e Desenvolvimento, Minas \\ Gerais, Brazil.
}

\begin{abstract}
The ability of crude extracts of the brown seaweed Spatoglossum schröederi to counteract some of the biological activities of Lachesis muta snake venom was evaluated. In vitro assays showed that only the extract of $S$. schröederi prepared in ethyl acetate was able to inhibit the clotting of fibrinogen induced by $L$. muta venom. On the other hand, all extracts were able to inhibit partially the hemolysis caused by venom and those prepared in dichloromethane or ethyl acetate fully neutralized the proteolysis and hemorrhage produced by the venom. Moreover, the dichloromethane or ethyl acetate extracts inhibited the hemolysis induced by an isolated phospholipase $\mathrm{A}_{2}$ from $L$. muta venom, called LM-PLA -I. In contrast, the hexane extract failed to protect mice from hemorrhage or to inhibit proteolysis and clotting. These results show that the polarity of the solvent used to prepare the extracts of $S$. schröederi algae influenced the potency of the inhibitory effect of the biological activities induced by $L$. muta venom. Thus, the seaweed $S$. schröederi may be a promising source of natural inhibitors of the enzymes involved in biological activities of L. muta venom.
\end{abstract}

Revista Brasileira de Farmacognosia Brazilian Journal of Pharmacognosy 22(4): 741-747, Jul./Aug. 2012

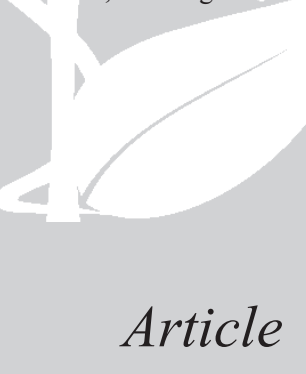

Received 28 Nov 2011

Accepted 20 Dec 2011

Available online 17 Apr 2012

Keywords:

Spatoglossum schröederi seaweed

Lachesis muta

snake venom bioprospecting

ISSN 0102-695X http://dx.doi.org/10.1590/S0102$695 \times 2012005000049$

\section{Introduction}

Marine organisms represent a valuable source of new compounds. The biodiversity of the marine environment, as well as its chemical diversity, constitute an unlimited source of substances that may lead to the development of bioactive products (Aneiros \& Garateix, 2004). Through their metabolism, marine organisms produce molecules, called secondary metabolites, with ecological functions such as defense against predators, competitors and herbivores and for prevention of biofouling (Clavico et al., 2006; Teixeira, 2009). Moreover, some pharmacological properties have been reported for such metabolites, including antimicrobial (González et al., 2001), antiviral (Cirne-Santos et al., 2008), anticancer (Rocha et al., 2007), antimalarial and antituberculosis (Jongaramruong \& Kongkam, 2007), antilonomic (Domingos et al., 2009) and antiophidic (Moura et al., 2010) activities. The brown algae (Phaeophyceae) are a class of almost exclusively marine organisms that have been extensively explored because of their biological potential, especially those of the family Dictyotaceae. The algae that belong to this family are the most studied and they produce a large amount of biologically-active substances, including terpenoids of different origins (De Paula et al., 2011). More than 300 diterpenes have been isolated from at least 35 species collected all over the world (Vallim et al., 2005). The genus Spatoglossum Kützing has twenty species but, despite this, only the diterpenoids spatane and secospatane were isolated from S. howellii Setchell \& N.L. Gardner and S. schmittii W. R. Taylor, respectively (Gerwick \& Fenical, 1983; Gerwick et al., 1983, De Paula et al., 2011).

Snakebite envenomation represents a serious health problem in tropical countries because of the high incidence and the sequels derived from accidents. Snake venoms are a complex mixture that induce a wide range of biological activities. Envenomation by the snake Lachesis muta (Linnaeus, 1766) results in systemic (hemostatic, renal, hemorrhage and neurotoxic disturbances) and local (edema, necrosis, inflammation, hemorrhage) signs and symptoms (Jorge et al., 1997; Fuly et al., 2002), which 
leads to high lethality and morbidity indexes (Ministério da Saúde, 2001).

The conventional treatment for snakebites is the parenteral administration of serum (antivenom), obtained from hyperimmunized equines, that is able to neutralize the toxic systemic effects. However, antivenom has several disadvantages such as: poor availability in distant regions, the potential for inducing allergic reactions and the lack of efficient neutralization of the local tissue damage induced by venoms (da Silva, 2007; Gutiérrez et al., 2009). Therefore, the search for venom inhibitors from either natural or synthetic sources that are able to act in concert with antivenom is relevant.

The present work reports the ability of extracts from the brown seaweed Spatoglossum schröederi (C. Agardh) Kützing to counteract the in vivo and in vitro activities of $L$. muta snake venom. Moreover, the inhibitory effect of seaweed was also evaluated against a phospholipase $\mathrm{A}_{2}$ enzyme (denoted LM-PLA2-I) previously isolated from this venom (Fuly et al., 1997).

\section{Materials and methods}

\section{Algae material}

Specimens of S. schröederi (Dictyotaceae, Phaeophyceae) were collected and identified by Dr. Roberto Villaça through snorkeling at depths ranging from 0 to $5 \mathrm{~m}$ at Atol das Rocas reef, Rio Grande do Norte

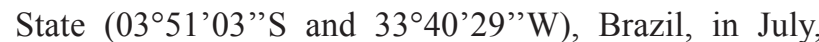
2009. Atol das Rocas reef is a marine biological reserve in northeast Brazil and is the only atoll in the South Atlantic. Seaweeds were washed with local sea water and separated from sediments, epiphytes or other associated organisms. The specimens are deposited in the herbarium of Dr. Roberto Villaça at the Department of Marine Biology, Universidade Federal Fluminense (UFF).

\section{Preparation of crude extract}

The air-dried algal material (109.3 g) was triturated and the extracts were obtained through an exhaustive and sequential extraction with solvents of increasing polarity: n-hexane, dichloromethane and ethyl acetate. For each extraction, the solvent was evaporated under reduce pressure and the chromatographic profiles of the extracts were observed on TLC plates $\left(\mathrm{SiO}_{2} 60, \mathrm{~F} 254\right)$ manufactured by Merck. The TLC plate was eluted with ethyl acetate: dichloromethane $(6: 4, \mathrm{v} / \mathrm{v})$ as the solvent system. The eluted plate was revealed by spraying with ceric sulfate, followed by heating at $120^{\circ} \mathrm{C}$.

\section{Snake venom and animals}

Lyophilized L. muta snake venom was provided by the Fundação Ezequiel Dias, Belo Horizonte-MG, Brazil, and LM-PLA 2 -I was isolated according to Fuly and collaborators (1997; 2002). Balb/c mice (18-20 g) were obtained from the Núcleo de Animais de Laboratório of the UFF. They were housed under controlled conditions of temperature $\left(24 \pm 1{ }^{\circ} \mathrm{C}\right)$ and light and all of the experiments performed were approved by the UFF Institutional Committee for Ethics in Animal Experimentation (CEPA: 200/10) and were in accordance with the guidelines of the Brazilian Committee for Animal Experimentation.

\section{Biological assays}

\section{Antihemolytic activity}

The degree of hemolysis induced by L. muta venom or LM-PLA - I was determined by the indirect hemolytic test using human erythrocytes and hen's egg yolk emulsion as substrate (Fuly et al., 2002). The amount of L. muta venom $(\mu \mathrm{g} / \mathrm{mL})$ that produced $80 \%$ hemolysis was denoted as the Minimum Indirect Hemolytic Dose (MIHD). Inhibitory experiments were performed by incubating S. schröederi extracts with one MIHD for 30 min at room temperature and then the hemolytic activity was evaluated. Control experiments were performed by incubating venom with DMSO or saline instead of $S$. schröederi extracts.

\section{Anticlotting assays}

The clotting activity of $L$. muta venom was determined using an Amelung Model KC4A coagulometer (Labcon, Germany). Different concentrations of L. muta venom were mixed with bovine fibrinogen solution ( $2 \mathrm{mg}$ / $\mathrm{mL}$ ) or with normal citrated human plasma (donated by the blood bank of Hospital Universitário Antônio Pedro, UFF). The amount of venom that clotted fibrinogen or plasma in $60 \mathrm{~s}$ was denoted as the Minimum Coagulant Dose (MCD). To evaluate the inhibitory effect, $S$. schröederi extracts were incubated for $30 \mathrm{~min}$ at room temperature with one MCD of venom. The mixture was then added to fibrinogen or plasma and the clotting time recorded. Control experiments were performed by incubating venom with DMSO or saline instead of $S$. schröederi extracts.

Hydrolytic activity upon chromogenic substrate

The hydrolysis of the chromogenic synthetic substrate S-2238 (used for monitoring thrombin-like enzymes) by L. muta venom was measured in a Thermomax Microplate reader (Molecular Devices, Menlo Park, CA, USA). L. muta venom was incubated for 30 min at room temperature with increasing concentrations of S. schröederi extracts. Then, reaction was triggered 
by adding $\mathrm{S}-2238(0.1 \mathrm{mM}$, final concentration) and the reaction was monitored at $405 \mathrm{~nm}$ at $37^{\circ} \mathrm{C}$. The reading obtained after $20 \mathrm{~min}$ of reaction in the absence of extract was taken as $100 \%$ activity and compared with the values in the presence of the extracts. Control experiments were performed by incubating $L$. muta venom with DMSO ( $1 \%$ $\mathrm{v} / \mathrm{v}$, final concentration) or saline.

\section{Antihemorrhagic activity}

Hemorrhagic lesions produced by L. muta venom were quantified by using a procedure described by Kondo et al. (1960) with minor modifications (Moura et al., 2010). Briefly, samples were injected intradermally (i.d.) into the abdominal skin of mice. Two hours later, the animals were euthanized and the abdominal skin removed, stretched and inspected for visual changes in the internal aspect in order to localize hemorrhagic spots. Hemorrhage was quantified as the Minimum Hemorrhagic Dose (MHD), defined as the amount of venom $(\mu \mathrm{g} / \mathrm{g})$ able to produce a hemorrhagic halo of $10 \mathrm{~mm}$ (Nikai et al., 1984). The inhibitory effect of $S$. schröederi extracts was investigated by incubating extracts with one MHD for $30 \mathrm{~min}$ at room temperature and the mixture was then injected into mice and hemorrhage measured. Hemorrhagic activity was expressed as the mean diameter (in millimeters) of the hemorrhagic halo induced by $L$. muta venom in the presence or in the absence of $S$. schröederi extracts. Negative control experiments were performed by injecting DMSO or saline.

\section{Antiproteolytic activity}

The proteolytic activity of $L$. muta venom was determined using azocasein as substrate $(0.2 \% \mathrm{w} / \mathrm{v}$, in $20 \mathrm{mM}$ Tris- $\mathrm{HCl}, 8 \mathrm{mM} \mathrm{CaCl}, \mathrm{pH} \mathrm{8.8),} \mathrm{with} \mathrm{minor}$ modification (Garcia et al., 1978; Moura et al., 2010). An effective concentration (EC) was defined as the amount of L. muta venom $(\mu \mathrm{g} / \mathrm{mL})$ able to produce a variation of about 0.2 OD units at $420 \mathrm{~nm}$. S. schröederi extract or DMSO alone were incubated with two EC of venom for $30 \mathrm{~min}$ at room temperature and then proteolysis was measured.

\section{Statistical analysis}

Results are expressed as the mean \pm SEM obtained with the indicated number of animals or experiments performed. The statistical significance of differences among experimental groups was evaluated using the Student's $t$ test and $p$ values of $\leq 0.05$ were considered statistically significant.

\section{Results and Discussion}

Bioprospection studies with marine organisms for the identification of active molecules are growing and different types of substances with high biotechnological and pharmacological potential have been isolated from them (Pereira et al., 2005; Mayer et al., 2011; CirneSantos et al., 2008; Abrantes et al., 2010; Bianco et al., 2009a, b). Previous studies showed the ability of dolastane and secodolastane diterpenes isolated from C. cervicornis marine brown alga to inhibit hemolytic, proteolytic, hemorrhagic and clotting activities of L. muta venom (Moura et al., 2010; Domingos et al., 2011). We have now evaluated the ability of $S$. schröederi algal extracts prepared with solvents of increasing polarities (n-Hexane, dichloromethane, ethyl acetate) to neutralize the hemolytic, proteolytic, hemorrhagic and clotting activities of crude $L$. muta venom.

The S. schröederi extracts $(90-900 \mu \mathrm{g} / \mathrm{mL})$ inhibited the hemolysis induced by L. muta venom (3.6 $\mu \mathrm{g} / \mathrm{mL})$ or LM-PLA 2 -I $(9.0 \mu \mathrm{g} / \mathrm{mL})$ in a concentrationdependent manner, but with potencies that varied according to the extraction solvent (Table 1). The extracts of alga prepared in dichloromethane at a 1:25 venom:alga ratio (w/w) inhibited $8.5 \%$ and $100 \%$ of the hemolysis induced by $L$. muta venom or LM-PLA -I, respectively (Table 1). A $100 \%$ inhibition of hemolysis was also observed for extracts of alga prepared in ethyl acetate, but not for the hexane ones. When compared to LM-PLA $-\mathrm{I}$, extracts of alga inhibited the hemolysis induced by L. muta venom less well (Table 1). Phospholipase $\mathrm{A}_{2}\left(\mathrm{PLA}_{2}\right.$ ) enzymes are considered to be the most active pharmacological component in snake venoms (De Paula et al., 2009). PLA enzymes are involved in prey digestion and also produce a wide range of pharmacological and toxic effects such as hemolysis, neurotoxicity, cardiotoxicity, effects on platelet aggregation, myotoxicity, and edema, that often contribute to the envenomation symptoms (Gutiérrez \& Ownby, 2003; Otero et al., 2000). L. muta venom contains $\mathrm{PLA}_{2}$ enzyme isoforms (Damico et al., 2008), one of which, denoted LM-PLA 2 -I, has been isolated (Fuly et al., 2002). As shown in Table 1, at a 1:25 venom:alga ratio, the ethyl acetate extract inhibited $30 \%$ and $60 \%$ of the hemolysis induced by L. muta venom or LM-PLA 2 -I, respectively. Curiously, at higher ratios (1:50 or 1:100), no inhibitory effect was achieved for L. muta venom. In contrast, at such ratios, the hemolysis induced by LM$\mathrm{PLA}_{2}$-I was totally inhibited (Table 1). At higher extract concentrations, less inhibition was observed for L. muta venom. At any concentration, S. schröederi extracts or DMSO did not induce hemolysis and DMSO did not interfere with the degree of hemolysis of L. muta venom or LM-PLA 2 -I (data not shown).

As shown in Figure 1A, proteolysis caused by L. muta venom $(0.75 \mu \mathrm{g} / \mathrm{mL})$ was inhibited by different concentrations of $S$. schröederi extracts (18.75, 37.5 and $75 \mu \mathrm{g} / \mathrm{mL}$ ). The dichloromethane and ethyl acetate 
extracts presented the highest inhibitory effect, from 90 to $100 \%$ at the three venom:alga ratios $(1: 25,1: 50$ and 1:100). The $n$-hexane extract inhibited proteolysis from 10 to $20 \%$ (Figure $1 \mathrm{~A}$, group 1). In vivo assays showed that intradermal injection of one MHD of $L$. muta venom $(1.2 \mu \mathrm{g} / \mathrm{g})$ produced a hemorrhage halo of about $10 \mathrm{~mm}$ in mice (data not shown). Figure 1B shows that only the extract prepared in ethyl acetate fully protected mice from hemorrhage caused by L. muta venom, while the $n$-hexane and dichloromethane extracts inhibited $4 \%$ and $40 \%$, respectively (Figure 1B). The animals that received saline or S. schröederi extracts showed no hemorrhagic halo (data not shown). We suggest that the inhibitory mechanism of action of $S$. schröederi extracts on hemorrhagic activity could occur through an interaction between compounds present in the alga and the catalytic sites of the metalloproteases of venom or, alternatively, such algal compounds might chelate metal ions $\left(\mathrm{Zn}^{2+}\right)$ that are essential for the enzymatic activity of the metalloproteases. Envenomation by L. muta venom usually produces hemorrhage due to the degradation of blood vessels or the consumption of fibrinogen or other blood clotting factors, thus preventing clot formation (Markland, 1998). Moreover, L. muta venom is a procoagulant. Hemorrhage or clotting effects are associated with specific protease groups, the metalloprotease and serine protease. A large number of bioactive molecules with anticoagulant activity have been described in marine organisms (Jurd et al., 1995; Lee et al., 1998; Mayer et al., 2011). These molecules are regularly produced via their primary or secondary metabolism, leading to the formation of polysaccharides (Camara et al., 2011) or diterpenes (Moura et al., 2010, 2011), respectively. Rocha et al. (2005) isolated polysaccharides from S. schröederi with potent in vivo antithrombotic effect upon venous thrombosis.

As observed in Figure 2A, even at the highest concentration $(62 \mu \mathrm{g} / \mathrm{mL})$ the three extracts of $S$. schröederi did not inhibit plasma clotting induced by $L$. muta venom $(0.62 \mu \mathrm{g} / \mathrm{mL})$, but at the same concentration the ethyl acetate extract inhibited clotting of commercial fibrinogen (Figure 2B). Hence, we infer that S. schröederi compounds somehow interfere with the serine protease enzymes of venom. DMSO did not affect the clotting induced by L. muta venom (Figure 2A, B). Thrombin, a serine protease enzyme, is a pivotal enzyme in the human clotting system. It is responsible for generating thrombus through the cleavage of fibrinogen, leading to formation of a fibrin net. Thrombin also induces platelet aggregation and may active other blood clotting factors. These effects are mediated by two distinct sites, a catalytic and a pharmacological one. To test the catalytic activity of thrombin or thrombin-like enzymes, a chromogenic substrate, S-2238, is often used. We therefore evaluated the ability of $S$. schröederi extracts to inhibit the hydrolysis of S-2238. Figure 3 shows that all extracts prevented hydrolysis by $L$. muta venom, suggesting that the anticlotting effect of $S$. schröederi extracts upon fibrinogen might be associated with thrombin-like enzymes present in L. muta venom. Again, the ethyl acetate extract proved to be the most powerful, since at 1:50 or $1: 100$ venom:alga ratios a 100\%-inhibition of the hydrolysis of S-2238 (Figure 3) or fibrinogen clotting (Figure 2) was seen.

Table 1. Antihemolytic effect of extracts of S. schröederi on $L$. muta venom or LM-PLA - I.

\begin{tabular}{|c|c|c|c|}
\hline $\begin{array}{c}\text { Venom source } \\
(\mu \mathrm{g} / \mathrm{mL})\end{array}$ & Solvent & $\begin{array}{c}\text { Algal } \\
\text { concentration } \\
(\mu \mathrm{g} / \mathrm{mL})\end{array}$ & $\begin{array}{l}\% \text { Inhibition } \\
\text { of hemolysis }\end{array}$ \\
\hline \multirow[t]{9}{*}{ L. muta } & $n$-hexane & 90 & $42 \pm 0.7$ \\
\hline & & 180 & $33 \pm 3.5$ \\
\hline & & 360 & $3.5 \pm 0.7$ \\
\hline & dichloromethane & 90 & $8.5 \pm 2.8$ \\
\hline & & 180 & $39 \pm 0.1$ \\
\hline & & 360 & 0 \\
\hline & ethyl acetate & 90 & $30 \pm 0.1$ \\
\hline & & 180 & 0 \\
\hline & & 360 & 0 \\
\hline \multirow[t]{9}{*}{ LM-PLA2-I } & $n$-hexane & 90 & 0 \\
\hline & & 180 & 0 \\
\hline & & 360 & 0 \\
\hline & dichloromethane & 90 & 100 \\
\hline & & 180 & 100 \\
\hline & & 360 & 100 \\
\hline & ethyl acetate & 90 & $62 \pm 5$ \\
\hline & & 180 & 100 \\
\hline & & 360 & 100 \\
\hline
\end{tabular}

$\overline{\text { L. muta venom }(3.6 \mu \mathrm{g} / \mathrm{mL}) \text { or LM-PLA }-\mathrm{I}(9.0 \mu \mathrm{g} / \mathrm{mL}) \text { was incubated }}$ with $S$. schröederi extracts at 1:25, 1:50 or 1:100 ratio (w/w) for 30 min at room temperature. Then, the hemolytic test was evaluated and percentage of inhibition of hemolysis analyzed. Data are expressed as mean \pm SEM of individuals experiments $(n=3)$.

Based on our results, the polarity of the solvents (n-hexane, dichloromethane and ethyl acetate) influenced on the inhibition profile for the biological activities evaluated in this work. The greater the polarity of the extraction solvent, the higher was the inhibitory percentage. This could be clearly observed since the dichloromethane and ethyl acetate extracts neutralized more efficiently all of the biological activities tested. As shown in Figure 4, extracts of $S$. schröederi subjected to TLC revealed heterogeneity in each extract composition. The lanes corresponding to the dichloromethane and ethyl acetate extracts showed the presence of more polar compounds than that of the hexane extract. Such differences in extract composition could explain the different inhibitory profiles 
of the extracts; and suggest that polar molecules are responsible for the observed inhibitory effects on $L$. muta biological activities.
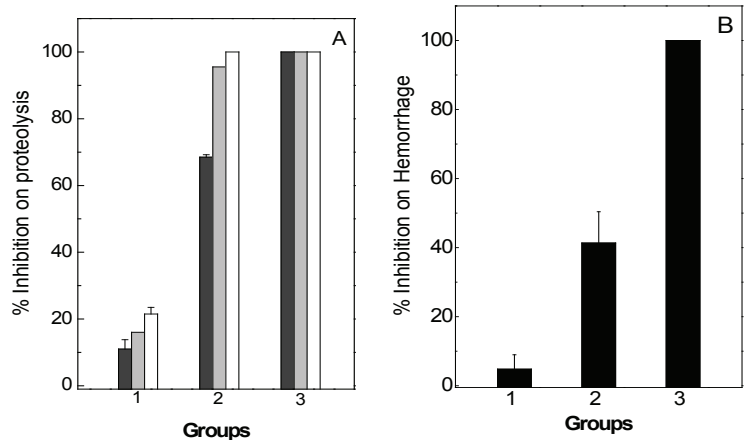

Figure 1. Antiproteolytic and antihemorrhagic effect of $S$. schröederi extracts. A. Inhibitory effect of S. schröederi extract at 1:25 (dark gray columns), 1:50 (gray columns) or 1:100 (white columns) venom: alga ratio $(\mathrm{w} / \mathrm{w})$ prepared in $n$-hexane (Group 1), dichloromethane (Group 2) or ethyl acetate (Group 3) upon proteolysis induced by $L$. muta venom $(0.75 \mu \mathrm{g} / \mathrm{mL})$. B. Inhibition of hemorrhage induced by $L$. muta venom $(1.2 \mu \mathrm{g} / \mathrm{g})$ in the presence of $18 \mu \mathrm{g} / \mathrm{g}$ of $S$. schröederi extracts prepared in n-hexane (Column 1), dichloromethane (Column 2) and ethyl acetate (Column 3). Data are expressed as mean \pm SEM of three individual experiments $(\mathrm{n}=3)$.
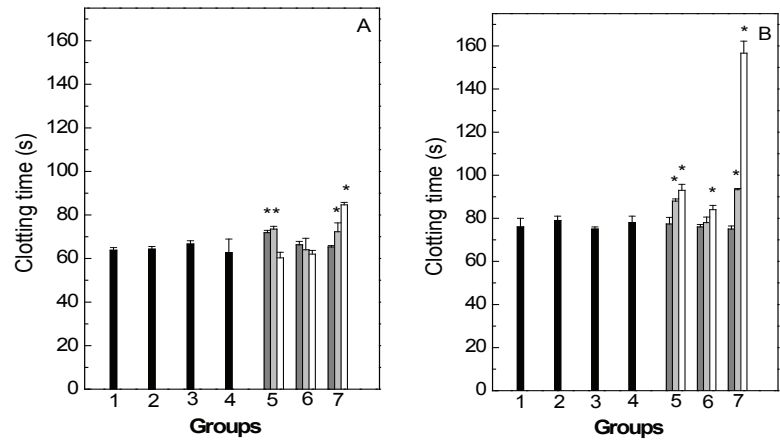

Figure 2. Anticlotting effects of $S$. schröederi crude extracts. Inhibitory effect of $S$. schröederi extracts prepared in $n$-hexane (Group 5), dichloromethane (Group 6) and ethyl acetate (Group 7) on clotting activity of human plasma (Panel A) and fibrinogen ( $2 \mathrm{mg} / \mathrm{mL}$ ) (Panel B) caused by L. muta venom $(0.62 \mu \mathrm{g} / \mathrm{mL})$ at 1:25 (dark gray columns), 1:50 (gray columns) or 1:100 (white columns) venom:alga ratio (w/w). Columns 1, 2, 3 and 4 represent coagulation induced by $L$. muta venom $(0.62 \mu \mathrm{g} /$ $\mathrm{mL}$ ) in the presence of $150 \mathrm{mM} \mathrm{NaCl}$ or $0.5,1$ and $2 \%$ DMSO ( $\mathrm{v} / \mathrm{v}$, final concentration), respectively. Data are expressed as mean \pm SEM of three individual experiments $(n=3)$. *Significance level $(p<0.05)$ when compared to column 1 of each panel.

In conclusion, $S$. schröederi extracts may be a promising source of molecules to improve the treatment against $L$. muta snakebites and may be useful for the development of new antiophidian molecules.

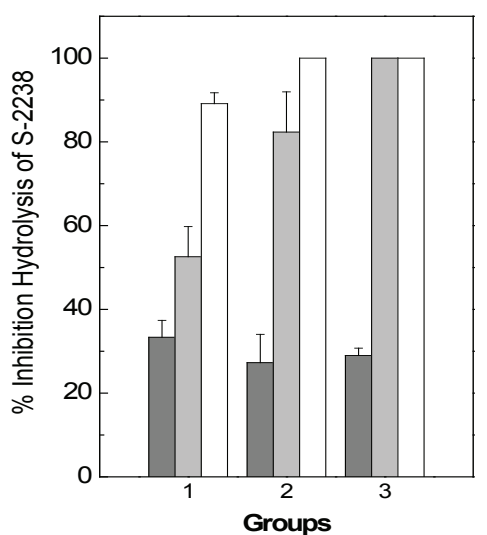

Figure 3. Effects of $S$. schröederi extracts on hydrolysis of S-2238. Inhibitory effect of $S$. schröederi extracts prepared in $n$-hexane (Group 1), dichloromethane (Group 2) and ethyl acetate (Group 3) on S-2238 hydrolysis caused by L. muta venom $(0.3 \mu \mathrm{g} / \mathrm{mL})$ at 1:25 (dark gray columns), 1:50 (gray columns) or 1:100 (white columns) venom:alga ratio (w/w). Data are expressed as mean \pm SEM of two individual experiments $(n=2)$.

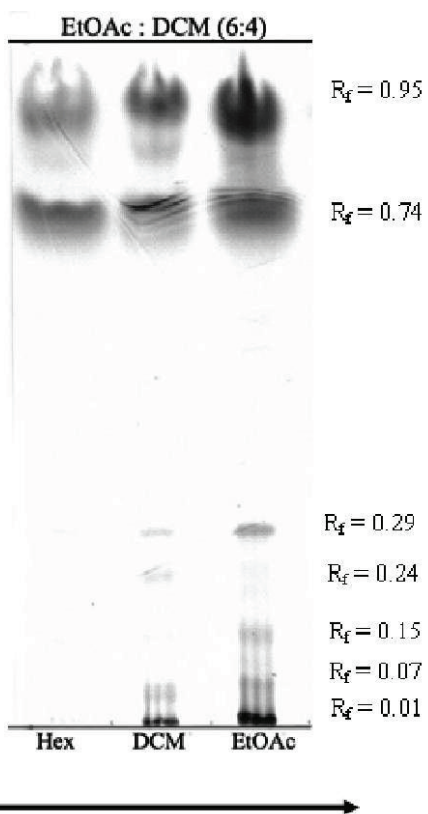

Polarity of solvents

Figure 4. TLC profile of S. schröederi extracts on Silica 60 F254 plates eluted with ethyl acetate:dichloromethane $(6: 4$, $\mathrm{v} / \mathrm{v}$ ) and revealed with ceric sulphate. Lanes are: Hex, extract in $n$-hexane; DCM, extract in dichloromethane; EtOAc, extract in ethyl acetate.

\section{Acknowledgments}

This work was supported by grants from the International Foundation for Science (IFS grant F/4571-1) and from Brazilian funding agencies: Conselho Nacional 
de Desenvolvimento Científico e Tecnológico, Fundação de Amparo à Pesquisa do Estado do Rio de Janeiro Carlos Chagas Filho, Coordenação de Aperfeiçoamento de Pessoal de Nível Superior and Universidade Federal Fluminense/Pró-reitoria de Pesquisa e Pós-graduação e Inovação.

\section{References}

Abrantes JL, Barbosa JP, Cavalcanti DN, Pereira RC, Fontes CFL, Teixeira VL, Souza TML, Paixão ICNP 2010. The effects of the diterpenes isolated from the Brazilian brown algae Dictyota pfaffii and Dictyota menstrualis against the herpes simplex type-1 replicative cycle. Planta Med 76: 339-344.

Aneiros A, Garateix A 2004. Bioactive peptides from marine sources: pharmacological properties and isolation procedures. J Chromatogr 803: 41-53.

Bianco EM, Teixeira VL, Pereira RC, Souza MT, Nucci P, Afonso IF, Rodrigues CR, Castro HC 2009a. Brown seaweeds defensive chemicals: structure-activity relationship approach for marine environment. Nat Prod Commun 4: 173-178.

Bianco EM, Rogers R, Teixeira VL, Pereira RC 2009b. Antifoulant diterpenes produced by the brown seaweed Canistrocarpus cervicornis. J Appl Phycol 21: 341-346.

Camara RBG, Costa LS, Fidelis GP, Nobre LTDB, DantasSanto N, Cordeiro SL, Costa MSSP, Alves LG, Rocha HAO 2011. Heterofucans from the brown seaweed Canistrocarpus cervicornis with anticoagulant and antioxidant activities. Mar Drugs 9: 124-138.

Cirne-Santos CC, Souza TML, Teixeira VL, Fontes CFL, Rebello MA, Castello-Branco LR, Abreu CM, Tanuri A, Frugulhetti IC, Bou-Habib DC 2008. The dolabellane diterpene dolabelladienetriol is a typical noncompetitive inhibitor of HIV-1 reverse transcriptase enzyme. Antivir Res 77: 64-71.

Clavico EEG, Muricy G, Gama BAP, Batista D, Ventura CRR, Pereira RC 2006. Ecological roles of natural products from the marine sponge Geodia corticostylifera. Mar Biol 148: 479-488.

Damico DC, da Cruz Höfling MA, Cintra M, Leonardo MB, Calgarotto AK, da Silva SL, Marangoni S 2008. Pharmacological study of edema and myonecrosis in mice induced by venom of the bushmaster snake (Lachesis muta muta) and its basic Asp49 phospholipase A(2) (LmTX-I). Protein J 27: 384-391.

da Silva NM, Arruda EZ, Murakami YL, Moraes RA, El-Kik CZ, Tomaz MA, Fernandes FF, Oliveira CZ, Soares AM, Giglio JR, Melo PA 2007. Evaluation of three Brazilian antivenom ability to antagonize myonecrosis and hemorrhage induced by Bothrops snake venoms in a mouse model. Toxicon 50: 196-205.

De Paula JC, Vallim MA, Teixeira VL 2011. What are and where are the bioactive terpenoids motabolites from
Dictyotaceae (Phaeophyceae). Rev Bras Farmacogn 21: 216-228.

De Paula RC, Castro HC, Rodrigues CR, Melo PA, Fuly AL 2009. Structural and pharmacological features of phospholipases $\mathrm{A}_{2}$ from snake venoms. Protein Pept Lett 16: 899-907.

Domingos TFS, Carvalho C, Moura LA, Teixeira VL, Pereira RC, Ramos CJ, Miranda ALP, Melo PA, Guimarães JA, Fuly AL 2009. Antilonomic effects of different Brazilian brown seaweeds crude extracts. Nat Prod Commun 4: 1075-1078.

Domingos TFS, Vallim MA, Carvalho C, Sanchez EF, Teixeira VL, Fuly AL 2011. Anti-snake venom effect of secodolastane diterpenes isolated from Brazilian marine brown alga Canistrocarpus cervicornis against Lachesis muta venom. Rev Bras Farmacogn 21: 234-238.

Fuly AL, Machado OL, Alves EW, Carlini CR 1997. Mechanism of inhibitory action on platelet activation of a phospholipase A2 isolated from Lachesis muta (Bushmaster) snake venom. Thromb Haemostasis 78: 1372-1380.

Fuly AL, Miranda AL, Guimarães JA 2002. Purification and characterization of phospholipase $\mathrm{A}_{2}$ isoenzyme isolated from Lachesis muta snake venom. Biochem Pharmacol 63: 1589-1597.

Garcia ES, Guimarães JA, Prado JL 1978. Purification and characterization of a sulfhydryl-dependent protease from Rhodnius prolixus midgut. Arch Biochem Biophys 188: 315-322.

Gerwick WH, Fenical W 1983. Spatane diterpenoids from the tropical marine algae Spatoglossum schmittii and Spatoglossum howleii (Dictyotaceae). J Org Chem 48: 3325-3329.

Gerwick WH, Fenical W, Engen DV, Clardy J 1983. Isolation and structure of spatol, a potent inhibitor of cell replication from the brown seaweed Spatoglossum schmittii. J Am Chem Soc 102: 7991-7993.

González del Val A, Platas G, Basílio A, Cabello A, Gorrochategui J, Suay I, Vicente F, Portilho E, Jiménez Del Rio M, Reina GG, Peláez F 2001. Screening of antimicrobial activities in red, green and brown macroalgae from Gram Canária (Canary Islands, Spain). Int Microbiol 4: 35-40.

Gutiérrez JM, Ownby CL 2003. Skeletal muscle degeneration induced by venom phospholipases $\mathrm{A}_{2}$ : insights into the mechanisms of local and systemic myotoxicity. Toxicon 42: 915-931.

Gutiérrez JM, Fan HW, Silvera CL, Angulo Y 2009. Stability, distribution and use of antivenoms for snakebite envenomation in Latin America: report of a workshop. Toxicon 53: 625-630.

Jongaramruong J, Kongkam N 2007. Novel diterpenes with cytotoxic, anti-malarial and anti-tuberculosis activities from a brown alga Dictyota sp. J Asian Nat Prod Res 9: 743-751. 
Jorge MT, Sano-Martins IS, Tomy SC, Castro SC, Ferrari RA, Ribeiro LA, Warrell DA 1997. Snakebite by the bushmaster (Lachesis muta) in Brazil: case report and review of the literature. Toxicon 35: 545-554.

Jurd KM, Rogers DJ, Blunden G, McLellan DS 1995. Anticoagulant properties of sulphated polysaccharides and a proteoglycan from Codium fragile ssp. atlanticum. J Appl Phycol 7: 339-345.

Kondo H, Kondo S, Ikezawa H, Murata R, Ohsaka A 1960. Studies on the quantitative methods for determination of hemorrhagic activity of Habu snake venom. Jpn J Med Sci Biol 13: 43-51.

Lee KH, Choi BD, Hong BI, Jung BC, Ruck JH, Jung WJ 1998. Functional properties of sulfated polysaccharides in ascidian (Halocynthia roretzi) tunic. J Korean Fish Soc 31: 447-451.

Markland FS 1998. Snake venoms and the hemostatic system. Toxicon 36: 1749-1800.

Mayer AM, Rodrígues AD, Berlinck RG, Fusetani N 2011. Marine pharmacology in 2007-8: Marine compounds with antibacterial, anticoagulant, antifungal, anti-inflammatory, antimalarial, antiprotozoal, antituberculosis, and antiviral activities; affecting the immune and nervous system, and other miscellaneous mechanisms of action. Comp Biochem Physiol 153: 191222.

Ministério da Saúde do Brasil. Fundação Nacional de Saúde 2001. Manual de diagnóstico e tratamento de acidentes por animais peçonhentos. 2. ed. Brasília: FUNASA, 120 p.

Moura LA, Sanchez EF, Bianco EM, Pereira RC, Teixeira VL, Fuly AL 2010. Antiophidian properties of a dolastane diterpene isolated from the marine brown alga Canistrocarpus cervicornis. Biomed Pharmacother, in press. DOI:10.1016/j.biopha.2010.09.023.

Moura LA, Bianco EM, Pereira RC, Teixeira VL, Fuly AL 2011. Anticoagulation and antiplatelet effects of a dolastane diterpene isolated from the marine brown alga Canistrocarpus cervicornis. J Thromb Thrombolys 31: 235-240.
Nikai T, Mori N, Kishida M, Sugihara H, Tu AT 1984. Isolation and biochemical characterization of hemorrhagic toxin from the venom of Crotalus atrox. Arch Biochem Biophys 231: 309-311.

Otero R, Núñez V, Jiménez SL, Fonnegra R, Osorio RG, García ME, Díaz A 2000. Snakebites and ethnobotany in the northwest region of Colombia part II: neutralization of lethal and enzymatic effects of Bothrops atrox venom. $J$ Ethnopharmacol 71: 505-511.

Pereira HS, Leão-Ferreira LR, Moussatche N, Cavalcanti DN, Teixeira VL, Da Costa LJ, Diaz R, Frugulhetti ICPP 2005. Effects of diterpenes isolated from the Brazilian marine alga Dictyota menstrualis on HIV-I reverse transcriptase. Planta Med 71: 1019-1024.

Rocha FD, Soares AR, Houghton PJ, Pereira RC, Kaplan MA, Teixeira VL 2007. Potential cytotoxic activity of some Brazilian seaweeds on human melanoma cells. Phytother Res 21: 170-175.

Rocha HAO, Moraes FA, Trindade ES, Franco CRC, Torquato RJS, Veiga SS, Valente AP, Mourão PAS, Leite EL, Nader HB, Dietrich CP 2005. Structural and hemostatic activities of a sulfated galactofucan from the brown alga Spatoglossum schröederi- an ideal antithrombotic agent? J Biol Chem 280: 41278-41288.

Teixeira VL 2009. Produtos naturais marinhos. In: Pereira RC, Soares-Gomes A (org.). Biologia Marinha. 2. ed. Rio de Janeiro: Editora Interciência, p. 443-472.

Vallim MA, De Paula JC, Pereira RC, Teixeira VL 2005. The diterpenes from Dictyotacean marine brown algae in the tropical Atlantic American region. Biochem Sys Ecol 33: $1-16$.

\section{*Correspondence}

André Lopes Fuly

Departamento de Biologia Celular e Molecular, Instituto de Biologia, Universidade Federal Fluminense, 24020-150 Niterói, RJ, Brazil andfuly@vm.uff.br Tel. +552126292294

Fax: +552126292376 